\title{
LEKSIKON-LEKSIKON DARI SARS-COV SAMPAI DENGAN COVID-19 SEBAGAI PENANDA SUATU PERISTIWA SEJARAH
}

\author{
Lexicon from SARS-CoV to COVID-19 as A Marker for a Historical Event
}

\author{
Sariah \\ Balai Bahasa Provinsi Jawa Barat \\ Jalan Sumbawa Nomor 11Bandung 40113 \\ E-mail: sariahsuwandi@gmail.com
}

\begin{abstract}
Each event gave birth to a lexicon or diction which became the main indicator in historical events, for example, the smallpox outbreak gave birth to a variant of the term of the disease, such as smallpox, chickenpox, shingles, smallpox, and so on. The period of the Covid-19 pandemic also gave birth to a lexicon that was characteristic of the Covid-19 pandemic. This pandemic with all its problems gave birth to an interesting lexicon to watch. This article raises the lexicon of the Covid-19 pandemic. The problem that is the focus of this paper is how the lexicons are revealed with all their variants during this pandemic. This study uses a descriptive method to describe the lexicon during a pandemic using the theory of (Kridalaksana, 2009a) and (Verhaar, 2001) regarding morphology. Data is downloaded from online media that has a lexicon around Covid-19, (Budi, 2020) and (Pasys, 2020). The findings are that the lexeme during the Covid-19 pandemic is expressed in primary lexeme (LP) by 33,3\%, secondary lexeme (LS) by $52,4 \%$, and abbreviations by $14,3 \%$. This lexicon is a unique lexicon that emerged as a result of the Covid-19 outbreak. The mask lexicon, Covid-19, regional quarantine, new normality, red zone, working from home (BDR), and PSBB are lexicons that are very familiar to Indonesian speakers during the Covid-19 pandemic. In addition, the lexicon is associated with a marker of a historical event in this case Covid-19, such as a historical event that occurred in an outbreak of smallpox, cholera, yellow which has a specific lexicon used.
\end{abstract}

Keywords: lexicon, pandemic, covid-19

\begin{abstract}
Abstrak
Setiap peristiwa melahirkan leksikon atau diksi yang menjadi indikator utama dalam peristiwa sejarah, misal wabah cacar melahirkan varian istilah dari penyakit tersebut, seperti cacar, cacar air, cacar api, cacar alas, dan sebagainya. Masa pandemi Covid-19 juga melahirkan leksikon yang menjadi karakteristik masa pandemi Covid-19. Pandemi ini dengan segala persoalannya melahirkan leksikon yang menarik untuk disimak. Tulisan ini mengangkat leksikon masa pandemi Covid-19. Masalah yang menjadi fokus tulisan ini adalah bagaimana leksikon-leksikon diungkap dengan semua variannya pada masa pandemi ini. Penelitian ini menggunakan metode deskriptif untuk memaparkan leksikon dalam masa pandemi dengan menggunakan teori (Kridalaksana, 2009b) dan (Verhaar, 2001) mengenai morfologi. Data diunduh dari media daring yang memiliki leksikon seputar Covid-19, yaitu Budi, 2020 dan Pasys, 2020 Temuannya adalah leksikon masa pandemi Covid-19 dinyatakan dalam leksem primer (LP) sebesar 33,3\%, leksem skunder (LS) sebesar 52,4\%, dan singkatan sebesar 14,3\%. Leksikon tersebut merupakan leksikon yang khas yang muncul akibat mewabahnya Covid-19. Leksikon masker, Covid-19, karantina wilayah, kenormalan baru, zona merah, bekerja dari rumah (BDR), dan $P S B B$ adalah leksikon yang sangat dikenal oleh penutur bahasa Indonesia pada masa pandemi Covid-19. Selain itu, leksikon tersebut dikaitkan dengan penanda suatu peristiwa sejarah dalam hal ini Covid-19, seperti peristiwa sejarah yang terjadi pada wabah cacar, kolera, kuning yang memiliki kekhasan leksikon yang digunakan.
\end{abstract}

Kata kunci: leksikon, pandemi, covid-1 


\section{PENDAHULUAN}

Awal dikenalnya virus korona adalah sejak tahun 1960. Virus ini diidentifikasi sebagai flu biasa yang telah menyerang 500 pasien pada masa itu. Saat itu, korona diperlakukan sebagai virus yang tidak mematikan dan dianggap sebagai virus yang sederhana sampai dengan tahun 2002 (Kumar, Dharmahendra, Rishabha Malviya, 2020). Setelah adanya Severe Acute Respiratory Syndrome (SARS-Cov) pada tahun 2002 di China, para pakar mulai bersungguh-sungguh mencari penyebab penyakit tersebut. Hasilnya adalah bahwa penyakit itu merupakan bentuk baru dari virus korona. Kondisi tersebut mengindikasikan bahwa virus korona mengalami mutasi dan perubahan serangan. Sementara itu, pada tahun 2012, terjadi wabah yang nyaris mirip dengan SARS-Cov, wabah itu adalah Middle East Respiratory Syndrome (MERS-Cov) di Timur Tengah (Kumar, Dharmahendra, Rishabha Malviya, 2020).

Dari tiga peristiwa (virus korona 1960, SARS-Cov 2002, MERS-Cov 2012 ), virus korona bukan virus yang stabil serta mampu berdaptasi menjadi lebih berbahaya dan dapat mengakibatkan kematian. Tiga peristiwa wabah yang terjadi tidak sampai ke Indonesia sehingga tidak menimbulkan kepanikan dan korban. Selain itu, tidak ada leksikon atau istilah yang harus dipahami karena tidak terjadi di Indonesia. Akan tetapi, ketika Covid-19 menyerang semua negara, Indonesia ada di dalamnya dan membutuhkan pengetahuan yang mudah untuk memahami Covid-19 dengan pencegahan, pengobatan, dan pasca kesembuhannya. Pengetahuan itu dibutuhkan masyarakat untuk dapat bersikap, berperilaku, dan berkontribusi dalam menghadapi Covid-19. Pengetahuan itu adalah senjata awal untuk meghindari, melindungi, dan mengobati jika Covid-19 menyerang mereka. Oleh karena itu, pengetahuan dalam bentuk leksikon atau istilah yang berkaitan dengan Covid-19 harus diperkenalkan dan diketahui masyarakat Indonesia. Covid-19 berasal dari Wuhan China dan menyebar ke seluruh dunia tentu menggunakan bahasa dunia yang popular, yaitu bahasa Inggris sehingga banyak leksikon atau istilah Covid-19 yang menggunakan bahasa Inggris. Akibatnya, banyak leksikon atau istilah yang harus diserap penuh, diadaptasikan, diterjemahkan, bahkan disingkat ke dalam bahasa Indonesia atau bahasa daerah sesuai kebutuhan masyarakat.

Masa pandemi Covid-19 telah melahirkan leksikon yang cukup banyak dan menggambarkan sebagian konsep yang belum ada sebelumnya. Pandemi tersebut menggunakan leksikon yang baru bagi penutur bahasa Indonesia atau mungkin penutur bahasa lain di dunia. Leksikon-leksikon tersebut dengan semua variannya menjadi sumber pengetahuan baru yang sangat mengayakan. Pada masa-masa sebelumnya leksikon menjadi penanda suatu peristiwa sejarah. Sebut saja pada masa pandemi cacar, banyak istilah yang digunakan seperti cacar, cacar air, cacar api, cacar alas dsb (Wulandari, Ari, Marsono, 2018). Masa tsunami banyak leksikon muncul manyapu pantai, gelombang tinggi, melululantakan daratan, dan sebagainya. Masa Orde Lama banyak ditemukan leksikon revolusi, ganyang, sikat, gilas, seperti ketika Presiden Soekarno mengumumkan kekesalannya dengan Malaysia dengan frasa membakar “Ganyang Malaysia”. Masa Orde Baru menggunakan leksikon yang bergaya eufemisme 
(menghaluskan makna atau melemahkan makna yang sebenarnya), seperti korupsi diganti komersialisasi jabatan, dipenjarakan diamankan. Ada beberapa leksikon juga masa Orde Baru sangat khas, seperti anti pembangunan, ekstrim kanan, ekstrim kiri, GPK, gangguan keamanan, subversi, mbalelo, penunggangan adu domba, dan seterusnya .

Penelitian mengenai Covid-19 sudah dilakukan oleh beberapa orang di antaranya adalah penelitian Sampurno dkk. (Sampurno, Muchammad Bayu Tejo, Tri Cahyo Kusumandyoko, n.d. 2020) yang berjudul "Budaya Media Sosial, Edukasi Masyarakat, dan Pandemi Covid-19”. Hasil penelitiannya menitikberatkan pada bagaimana media mempengaruhi masyarakat dengan melibatkan komunikasi media massa dalam strategi untuk meningkatkan kesadaran tentang usaha penanganan dan pencegahan Covid-19. Penelitian lainnya adalah penelitian Akbari (Akbari, 2020) bagaimana eksistensi bahasa daerah di masa pandemi Covid-19. Adapun yang menjadi pengamatan adalah pesan berbahasa Banjar yang ditampilkan berkaitan dengan situasi pandemi Covid-19. Penelitian berikutnya adalah penelitian Ristyawati (Ristyawati, 2020) yang berjudul "Efektifitas Kebijakan Pembatasan Sosial Berskala Besar Dalam Masa Pandemi Corona Virus 2019 oleh Pemerintah Sesuai Amanat UUD NRI Tahun 1945". Penelitiannya bertujuan untuk mengetahui efektifitas kebijakan pemerintah pada masa pandemi dan bagaimana upaya yang dilakukan agar kebijakan yang diberikan selama masa Pandemi efektif sesuai UUD NRI Tahun 1945. Penelitian selanjutnya adalah penelitian Nugraha (Nugraha, 2020) yang berjudul "Kearifan Lokal dalam Menghadapi Pandemi Covid-19: Sebuah Kajian Literatur". Temuannya adalah beberapa kearifan lokal yang dimiliki masyarakat Baduy dapat memitigasi pandemi Covid-19 yang tergambarkan pada tradisi perladangan, aturan dalam membuat bangunan, dan hutan sebagai tempat perlindungan.

Dari empat penelitian mengenai Covid-19, belum ada penelitian yang mengangkat mengenai leksikon dari SAR-Cov sampai dengan Covid-19 sebagai penanda suatu peristiwa sejarah. Oleh karena itu, leksikon-leksikon masa pandemi Covid-19 menarik untuk diteliti karena setiap petaka, termasuk petaka pandemi melahirkan leksikon yang menjadi penanda masa pandemi tersebut.

Berdasarkan paparan di atas masalah dalam penelitian ini adalah bagaimana leksikon-leksikon masa pandemi Covid-19 lahir dan menjadi leksikon baru yang digunakan dalam masa pandemi ini. Tujuan penelitian ini adalah menjelaskan dan mendeskripsikan leksikon masa pandemi yang digunakan dan menjadi leksikon baru yang seksi karena wara-wiri dalam penggunaan bahasa sehari-hari dan menjadi ciri atau penanda suatu wabah, yaitu masa pandemi Covid-19 sekaligus menjadi penanda suatu peristiwa sejarah.

Penelitian ini menggunakan metode deskriptif kualitatif yang menggambarkan leksikon-leksikon masa pandemi Covid-19 yang diunduh dari media daring (Budi, 2020) dan (Pasys, 2020). Pengumpulan data dalam penelitian ini menggunakan metode dokumentasi, yaitu simak, bebas, libat, dan cakap (SBLC) dengan teknik catat. Analisis data dalam penelitian ini dilakukan dengan metode padan ekstralingual. 
Metode padan ekstralingual adalah analisis bahasa dengan menghubung-hubungan unsur kebahasaan dengan hal yang berada di luar bahasa (Mahsun, 2014). Metode padan ekstralingual dalam penelitian ini digunakan untuk mengidentifkasi bentukbentuk leksikon. Tahap analisis data menggunakan teknik (1) reduksi data yang mencakup identifikasi, pengenalan, dan pengkodean tentang unit bahasa yang termasuk leksikon Covid-19; (2) analisis data yang mengandung leksikon dengan memperhatikan aspek konteks, kekuatan, dan perumusan kelemahan bahasa; (3) verifikasi dan interpretasi data.

Tulisan ini menggunakan teori Kridalaksana (Kridalaksana, 2009) dan Veerhar (Verhaar, 2001) tentang morfologi yang di dalamnya memuat leksem, leksikon, singkatan, adaptasi, dan sebagainya. Namun, dalam perincian tulisan menggunakan pembagian leksem menurut Berlin (dalam Wulandari, Ari, Marsono, 2018:217).

\section{PEMBAHASAN}

Leksikon masa pandemi Covid-19 berwujud dalam kata dan frasa. Akan tetapi, untuk menunjuk istilah itu secara teknis menggunakan istilah leksem atau leksikon yang mengikuti konsep Berlin, (dalam Wulandari, Ari, Marsono, 2018). Istilah yang digunakan untuk menandai leksikon masa pandemi Covid-19 menggunakan leksem (lexeme), bukan kata (word) karena pemakaian kata lebih kompleks yang berkaitan juga dengan proses pengimbuhan. Oleh karena itu, Lyons (J. Lyons, 1968) mengusulkan penggunaan leksem daripada kata. Berlin (dalam Wulandari, Ari, Marsono, 2018) menggunakan istilah leksem untuk menandai unit terkecil dari bahasa. Leksem merupakan unit semantis dalam taksonomi. Menurutnya, leksem terdiri atas dua macam, yaitu leksem primer (LP) dan leksem sekunder (LS). LP umumnya lebih mudah dikenali dibandingkan dengan LS karena bentuk LP lebih sederhana dibandingkan dengan bentuk LS. Leksikon masa pandemi Covid-19 berwujud LP dan LS. LP lebih muda dikenali karena hanya satu unsur atau satu leksem yang berupa kata monomorfemis, sedangkan LS dapat terdiri atas dua atau tiga leksem yang berupa kata polimorfemis.

Berdasarkan analisis data ditemukan leksikon masa pandemi Covid-19 berupa LP dan LS. LP berjumlah 14 leksem, LS berjumlah 22 leksem, dan singkatan berjumlah 6 leksem. Total leksemnya berjumlah 42 leksem. Leksikon-leksikon tersebut bersifat khas yang mengacu pada masa pandemi Covid-19. Karena kekhasannya tersebut, leksikon masa pandemi Covid-19 dapat menjadi penanda suatu peristiwa sejarah yang terjadi di Indonesia secara khusus dan di dunia secara umum.

\section{Leksem Primer}

LP itu adalah wabah, epidemi, pandemi, sindemi, droplet, novel, isolasi, karantina, inkubasi, imun, ventilator, skrining, klorokuin, dan masker. Empat belas leksem masa pandemi Covid-19 adalah LP yang sering terdengar dalam komunikasi sehari-hari juga klausa ajakan menggunakan masker, mencuci tangan, dan menjaga jarak.

Penutur bahasa Indonesia mengenali leksikon (1)--(14) tersebut sebagai leksikon 
masa pandemi Covid-19. Leksikon adalah komponen bahasa yang memuat semua informasi tentang makna dan pemakaian kata dalam bahasa (Kridalaksana, 1993:127). Jadi, leksikon adalah penampakan atau rupa komponen bahasa yang memuat semua informasi tentang makna dan pemakaian kata dalam bahasa yang merujuk pada makna leksikon masa pandemi Covid-19. Makna setiap leksikon menggunakan Kamus Besar Bahasa Indonesia (Nasional, 2008)

jika tidak ditemukan, makna dicari google.com. Untuk jelasnya, bentuk-bentuk LP dapat dilihat pada Tabel 1 berikut.

\begin{tabular}{|c|c|c|c|}
\hline No & Leksem Primer & Makna & Contoh Kalimat \\
\hline 1 & Wabah & $\begin{array}{l}\text { Penyakit menular yang berjangkit } \\
\text { dengan cepat, menyerang sejumlah } \\
\text { besar orang di daerah yang luas } \\
\text { (cacar, kolera) }\end{array}$ & $\begin{array}{l}\text { Wabah Covid-19 telah membuat } \\
\text { perubahan masyarakat }\end{array}$ \\
\hline 2 & Epidemi & $\begin{array}{l}\text { Penyakit menular yang berjangkit } \\
\text { dengan cepat di daerah yang luas } \\
\text { dan menimbulkan banyak korban, } \\
\text { misalnya penyakit yg tidak secara } \\
\text { tetap berjangkit di daerah itu }\end{array}$ & $\begin{array}{l}\text { Sebuah epidemi telah menyebar ke } \\
\text { beberapa negara }\end{array}$ \\
\hline 3 & Pandemi & $\begin{array}{l}\text { Wabah yang berjangkit serempak } \\
\text { di mana-mana, meliputi daerah } \\
\text { geografi yang luas }\end{array}$ & $\begin{array}{lcr}\text { Beberapa } & \text { ilmuwan di } & \text { dunia } \\
\text { menyebut virus Corona } & \text { bukan } \\
\text { sebagai pandemi } & & \\
\end{array}$ \\
\hline 4 & Sindemi & $\begin{array}{l}\text { Sindemi merupakan usaha } \\
\text { menyatukan sinergi dan pandemi. } \\
\text { Disebut sebagai sindemi saat ada } \\
\text { dua atau lebih penyakit berinteraksi }\end{array}$ & $\begin{array}{l}\text { Sindemi adalah perpaduan antara } \\
\text { COVID-19 diabetes, kanker, dan } \\
\text { juga jantung }\end{array}$ \\
\hline 5 & Droplet & $\begin{array}{l}\text { Cairan atau cipratan liur yang } \\
\text { dikeluarkan seseorang dari hidung } \\
\text { atau mulut saat bersin, batuk, } \\
\text { bahkan berbicara }\end{array}$ & $\begin{array}{ll}\text { Metode transmisi } & \text { COVID-19 } \\
\text { adalah melalui droplet } & \end{array}$ \\
\hline 6 & Novel & $\begin{array}{l}\text { Novel berarti "baru". Jadi, Novel } \\
\text { Corona Virus adalah jenis yang } \\
\text { belum terdeteksi pada manusia } \\
\text { sebelumnya }\end{array}$ & $\begin{array}{l}\text { COVID-19, juga dikenal sebagai } \\
\text { Novel Coronavirus } 2019\end{array}$ \\
\hline 7 & Isolasi & $\begin{array}{l}\text { Pengasingan, tindakan pemisahan } \\
\text { pasien berpenyakit menular dari } \\
\text { orang lainnya }\end{array}$ & $\begin{array}{l}\text { Isolasi adalah } \quad \text { tindakan } \\
\text { memisahkan orang yang sudah } \\
\text { sakit dengan orang sehat untuk } \\
\text { mencegah penyebaran virus korona }\end{array}$ \\
\hline 8 & Karantina & $\begin{array}{l}\text { Tempat penampungan yg lokasinya } \\
\text { terpencil guna mencegah terjadinya } \\
\text { penularan penyakit dan sebagainya }\end{array}$ & $\begin{array}{l}\text { Isolasi dan karantina bisa dilakukan } \\
\text { dengan bantuan tenaga medis di } \\
\text { rumah sakit }\end{array}$ \\
\hline 9 & Inkubasi & $\begin{array}{l}\text { Masa dari saat penyebab penyakit } \\
\text { masuk ke dalam tubuh sampai ke } \\
\text { saat timbulnya penyakit itu }\end{array}$ & $\begin{array}{l}\text { Akhir masa inkubasi ditandai } \\
\text { dengan timbulnya gejala, seperti } \\
\text { batuk dan demam }\end{array}$ \\
\hline 10 & Imun & Kebal terhadap suatu penyakit & $\begin{array}{l}\text { Sitem imun berperan dalam } \\
\text { mengenal, menghancurkan benda- } \\
\text { benda asing atau sel abnormal yang } \\
\text { merugikan tubuh }\end{array}$ \\
\hline 11 & Ventilator & Peralatan & Ventilator akan memompa udara \\
\hline
\end{tabular}




\begin{tabular}{|c|c|c|c|}
\hline & & $\begin{array}{l}\text { menghasilkan putaran udara untuk } \\
\text { membantu pasien bernapas }\end{array}$ & $\begin{array}{l}\text { selama beberapa detik untuk } \\
\text { menyalurkan oksigen ke paru-paru } \\
\text { pasien }\end{array}$ \\
\hline & Skrining & $\begin{array}{l}\text { Penapisan, deteksi dini dari suatu } \\
\text { penyakit atau usaha untuk } \\
\text { mengidentifikasi penyakit atau } \\
\text { kelainan secara klinis belum jelas } \\
\text { dengan menggunakan tes }\end{array}$ & $\begin{array}{lll}\text { Skrining } & \text { adalah } & \text { pemeriksaan } \\
\text { kesehatan } & & \\
\end{array}$ \\
\hline & Klorokuin & $\begin{array}{l}\text { Obat antimalaria yang digunakan } \\
\text { untuk mencegah } \\
\text { mengatasi malaria. Saat dan } \\
\text { klorokuin sedang diteliti untuk } \\
\text { menangani infeksi virus korona } \\
\text { atau Covid-19 }\end{array}$ & $\begin{array}{l}\text { Sebagai obat antimalaria, klorokuin } \\
\text { bekerja dengan cara menghambat } \\
\text { pertumbuhan parasit plasmodium } \\
\text { di dalam sel darah merah }\end{array}$ \\
\hline & Masker & Kain penutup mulut dan hidung & $\begin{array}{l}\text { Masker yang menutup mulutnya } \\
\text { bertali ke telinga }\end{array}$ \\
\hline
\end{tabular}

Tabel 1. Leksem Primer Masa Pandemi Covid-19

(Sumber: Budi, 2020 dan Pasys, 2020)

Dari 14 LP masa pandemi Covid-19, mungkin masih ada yang belum teridentifikasi seluruhnya, seperti istilah sindemi baru saja dimuat 13 November 2020. Sindemi merupakan leksikon baru masa pandemi Covid-19 yang berupa paduan dari epidemi dan pandemi. Selain itu, leksikon masker paling dikenal masa pandemi Covid-19 karena selalu diulang-ulang dalam slogan untuk menggunakan masker. Masker menjadi kata kunci dalam pasa pandemi ini.

\section{Leksem Sekunder}

Bentuk LS masa pandemi Covid-19 terdiri atas dua, yaitu (1) LS dua leksem dan (2) LS tiga leksem. LS dua leksem masa pandemi Covid-19 adalah virus sars, virus mers, virus korona, Covid-19, suspek korona, karantina wilayah, karantina mandiri, tes rapid, tes swab, pembersih tangan, viral loaf, kekebalan kelompok (herd immunity), kurva melandai, kenormalan baru, zona hitam, zona merah, zona kuning, dan zona hijau. Jadi, LS dengan dua leksem berjumlah 18 buah.

LS dengan tiga leksem adalah pembatasan jarak sosial, pembatasan jarak fisik, bekerja dari rumah, dan di rumah saja. LS dengan tiga leksem tersebut berjumlah 4 buah dan yang paling terkenal adalah bekerja dari rumah (BDR) dari bahasa Inggris work from home (WFH). Leksikon-leksikon tersebut merupakan istilah baru yang memberi masukan terhadap pengayaan kosakata bahasa Indonesia. Wabah tidak saja menimbulkan masalah yang pelik, tetapi juga menambah leksikon yang bersifat mengayakan diksi dalam bahasa Indonesia. Jika suatu saat generasi hari ini mengingat masa pandemi Covid-19 dalam perjalanan hidupnya ke depan, istilah-istilah tersebut akan menguak ingatannya betapa mengerihkan dan merepotkan apa yang mereka rasakan pada waktu itu. Untuk jelasnya LS masa pandemi Covid-19, dapat dilihat dari Tabel 2 berikut. 


\begin{tabular}{|c|c|c|c|}
\hline No & Leksem Sekunder & Makna & Contoh Kalimat \\
\hline 1 & Virus mers & $\begin{array}{lll}\text { Middle } & \text { East } & \text { Respiratory } \\
\text { Syndrome } & & \end{array}$ & $\begin{array}{l}\text { Penyakit MERS adalah penyakit } \\
\text { saluran pernapasan yang disebabkan } \\
\text { oleh virus korona. }\end{array}$ \\
\hline 2 & Virus sars & $\begin{array}{lll}\text { Severe Acute } & \text { Respiratory } \\
\text { Syndrome } & & \\
\end{array}$ & $\begin{array}{l}\text { SARS menyebar ke seluruh dunia } \\
\text { meskipun dapat segera dibendung. }\end{array}$ \\
\hline 3 & $\begin{array}{l}\text { Virus korona (Corona } \\
\text { virus) }\end{array}$ & $\begin{array}{l}\text { Virus korona yang masih } \\
\text { berhubungan dengan MERS dan } \\
\text { SARS }\end{array}$ & $\begin{array}{l}\text { Sampai saat ini belum ada vaksin } \\
\text { untuk mencegah infeksi virus } \\
\text { korona. }\end{array}$ \\
\hline 4 & Covid-19 & $\begin{array}{l}\text { Novel Coronavirus (menyebabkan } \\
\text { wabah pneumonia di kota Wuhan, } \\
\text { Tiongkok pada Desember } 2019 .\end{array}$ & $\begin{array}{l}\text { Gejala infeksi virus korona atau } \\
\text { COVID-19 tak kunjung membaik } \\
\text { dalam hitungan hari. }\end{array}$ \\
\hline 5 & $\begin{array}{l}\text { Suspek korona } \\
(\text { Suspect Corona })\end{array}$ & $\begin{array}{l}\text { Suspek sendiri berasal dari } \\
\text { kata suspect dalam bahasa Inggris } \\
\text { yang berarti "tersangka, diduga, } \\
\text { atau yang dicurigai }\end{array}$ & $\begin{array}{lll}\text { Mereka yang dinyatakan } & \text { sebagai } \\
\text { suspek virus korona } & \text { memiliki } \\
\text { beberapa gejala dari } & \text { penyakit } \\
\text { tersebut. } & & \\
\end{array}$ \\
\hline 6 & Karantina Wilayah & $\begin{array}{l}\text { Karantina Wilayah adalah } \\
\text { pembatasan penduduk dalam } \\
\text { suatu wilayah termasuk wilayah } \\
\text { Pintu Masuk beserta isinya yang } \\
\text { diduga terinfeksi penyakit } \\
\text { dan/atau terkontaminasi. }\end{array}$ & $\begin{array}{l}\text { Pasal } 1 \text { Ketentuan Umum undang- } \\
\text { undang ini mencantumkan apa yang } \\
\text { dimaksud dengan karantina wilayah }\end{array}$ \\
\hline 7 & $\begin{array}{lr}\text { Pembatasan } & \text { jarak } \\
\text { Sosial } & \text { (Social } \\
\text { Distancing) } & \end{array}$ & $\begin{array}{l}\text { Menjaga jarak sosial (hindari } \\
\text { mobilitas sosial) }\end{array}$ & $\begin{array}{l}\text { Dalam upaya menangani wabah } \\
\text { virus korona, pemerintah } \\
\text { menganjurkan masyarakat untuk } \\
\text { menerapkan pembatasan jarak sosial }\end{array}$ \\
\hline 8 & $\begin{array}{lr}\text { Pembatasan } & \text { Jarak } \\
\text { Fisik } & \text { (Physical } \\
\text { Distancing) } & \end{array}$ & Menjaga jarak fisik & $\begin{array}{l}\text { Pembatasan fisik adalah salah satu } \\
\text { langkah yang disarankan untuk } \\
\text { mencegah penyebaran virus korona. }\end{array}$ \\
\hline 9 & Karantina Mandiri & $\begin{array}{l}\text { Mengisolasi diri secara mandiri } \\
\text { (tidak keluar ruangan atau tidak } \\
\text { keluar rumah) }\end{array}$ & $\begin{array}{l}\text { Masyarakat juga diminta untuk } \\
\text { melakukan karantina mandiri demi } \\
\text { mencegah penyebaran virus lebih } \\
\text { lanjut. }\end{array}$ \\
\hline 10 & $\begin{array}{l}\text { Tes Rapid (Rapid } \\
\text { Test) }\end{array}$ & Tes rapid & $\begin{array}{l}\text { Pemerintah sudah mulai melakukan } \\
\text { tes rapid ( rapid test) di beberapa } \\
\text { wilayah di Indonesia. }\end{array}$ \\
\hline 11 & Tes swab (Test swab) & Tes usap dahak & $\begin{array}{l}\text { Tes swab memiliki akurasi yang } \\
\text { lebih tepat untuk mendeteksi infeksi } \\
\text { akibat virus korona }\end{array}$ \\
\hline 12 & $\begin{array}{l}\text { Pembersih tangan } \\
\text { (Hands Sanitizer) }\end{array}$ & Cairan pembersih tangan & $\begin{array}{l}\text { Hands sanitizer menjadi alternatif } \\
\text { untuk membersihkan tangan. }\end{array}$ \\
\hline 13 & $\begin{array}{l}\text { Work from home } \\
\text { (WFH) }\end{array}$ & Bekerja dari rumah (BDR) & $\begin{array}{l}\text { WFH adalah singkatan dari work } \\
\text { from home yang berarti bekerja dari } \\
\text { rumah }\end{array}$ \\
\hline 14 & Di rumah saja & Jaga diri dari penularan & $\begin{array}{l}\text { Di rumah saja bukan jadi orang } \\
\text { malas berkarya }\end{array}$ \\
\hline 15 & Viral load & $\begin{array}{l}\text { Menggambarkan jumlah virus } \\
\text { dalam darah }\end{array}$ & $\begin{array}{l}\text { Gagalnya terapi ARV pada ODHA } \\
\text { dapat dicegah dengan pemeriksaan }\end{array}$ \\
\hline
\end{tabular}




\begin{tabular}{|c|c|c|c|}
\hline & & & viral load \\
\hline 16 & $\begin{array}{l}\text { Kekebalan kelompok } \\
\text { (Herd Immunity) }\end{array}$ & $\begin{array}{l}\text { Kekebalan kelompok atau } \\
\text { kekebalan kawanan adalah suatu } \\
\text { bentuk perlindungan tidak } \\
\text { langsung dari penyakit menular } \\
\text { yang terjadi ketika sebagian besar } \\
\text { populasi menjadi kebal terhadap } \\
\text { infeksi, baik melalui infeksi } \\
\text { sebelumnya atau vaksinasi, } \\
\text { sehingga individu yang tidak } \\
\text { kebal ikut terlindungi }\end{array}$ & $\begin{array}{l}\text { Herd immunity adalah } \\
\text { sebagian besar populasi kebal } \\
\text { terhadap penyakit menular tertentu } \\
\text { sehingga memberikan perlindungan } \\
\text { tidak langsung atau kekebalan } \\
\text { kelompok bagi mereka yang tidak } \\
\text { kebal terhadap penyakit menular } \\
\text { tersebut }\end{array}$ \\
\hline 17 & $\begin{array}{l}\text { Kurva melandai } \\
\text { (Flattening the curve) }\end{array}$ & kurva melandai & $\begin{array}{l}\text { Salah satunya adalah dengan rumus } \\
\text { ajaib yaitu flattening the curve atau } \\
\text { melandaikan kurva. }\end{array}$ \\
\hline 18 & $\begin{array}{l}\begin{array}{l}\text { Kenormalan } \\
\text { (new normal) }\end{array} \\
\end{array}$ & $\begin{array}{l}\text { Aktivitas yang } \quad \text { tetap } \\
\text { menggunakan protokol kesehatan }\end{array}$ & $\begin{array}{l}\text { Kenormalan baru mengajarkan } \\
\text { masyarakat hidup disiplin }\end{array}$ \\
\hline 19 & Zona Hitam & 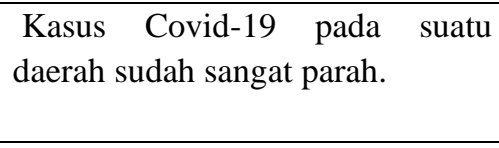 & $\begin{array}{l}\text { Angka kasus baru di atas } 2000 \text {-an } \\
\text { maka daerah itu akan berwarna } \\
\text { merah. Jadi tampak seperti hitam }\end{array}$ \\
\hline 20 & Zona Merah & $\begin{array}{l}\text { Masih ada kasus Covid-19 pada } \\
\text { satu atau lebih klaster dengan } \\
\text { peningkatan kasus yang tinggi. }\end{array}$ & $\begin{array}{l}\text { Dalam kasus zona merah, diperlukan } \\
\text { protokol kesehatan yang serius, } \\
\text { seperti menutup sekolah, tempat } \\
\text { ibadah, dan bisnis }\end{array}$ \\
\hline 21 & Zona Kuning & $\begin{array}{l}\text { Ada beberapa kasus Covid-19 } \\
\text { dengan beberapa penularan lokal. }\end{array}$ & $\begin{array}{l}\text { Zona kuning akan } \\
\text { menerapkan protokol kesehatan yang } \\
\text { sama dengan zona hijau }\end{array}$ \\
\hline 22 & Zona Hijau & $\begin{array}{l}\text { sebuah wilayah atau daerah sudah } \\
\text { tidak ada kasus atau infeksi virus } \\
\text { corona }\end{array}$ & $\begin{array}{l}\text { Wilayah zona hijau tetap perlu ada } \\
\text { kesadaran masyarakat untuk } \\
\text { meningkatkan jarak sosial, cuci } \\
\text { tangan, hingga pemakaian masker }\end{array}$ \\
\hline
\end{tabular}

\section{Tabel 2. Leksem Skunder Masa Pandemi Covid-19}

(Sumber: Budi, 2020 dan Pasys, 2020)

LS terdiri atas dua konstituen dengan posisi yang berbeda. Salah satu konstituen dalam ekspresi LS merupakan inti (diterangkan atau D) atau superordinat dan konstituen yang lain merupakan bawahan bukan inti (menerangkan atau $\mathrm{M}$ ) atau subordinat. Superordinat dan subordinat adalah istilah-istilah yang berkaitan dengan hubungan semantik antara makna khusus/Specific (S) dan makna umum/Generic (G), atau antara anggota taksonomi dan nama taksonomi. Misalnya, antara melati, mawar, dan lili di satu pihak dan bunga. Bunga disebut superordinat (hiponim) dari melati, mawar, dan lili. Melati, mawar, dan lili disebut subordinat (kohiponim) (Kridalaksana, 2009). Identifikasi LS pada leksikon masa pandemi Covid-19 dapat dilakukan pada LS dengan dua leksem bawahan dan pada LS dengan tiga leksem bawahan seperti berikut. Pertama, pada bentuk virus korona merupakan LS yang (a) salah satu konstituennya, virus, sebagai label taksonomi yang menjadi superordinat, dan (b) konstituen lainnya, korona. Contoh varian lain adalah virus mers dan virus sars dengan superordinat pada leksem virus serta subordinatnya adalah mers dan sars. 
LS yang terdiri atas tiga leksem terdapat pada pembatasan jarak sosial. Pada bentuk pembatasan jarak sosial, LS tersebut adalah (a) salah satu konstituennya, pembatasan jarak merupakan label taksonomi yang menjadi atasannya langsung atau superordinat, dan (b) konstituen lainnya, sosial menjadi subordinat dan satu kelompok yang anggotanya juga diberi label oleh LS yang mencakup konstituen berlabel taksonomi pembatasan jarak, yaitu pembatasan jarak sosial, pembatasan jarak fisik. Ini merupakan LS dengan tiga leksem bawahan atau LS yang terdiri dari tiga leksem.

\section{Leksem Singkatan}

Bentuk singkatan juga ditemukan dalam leksikon masa pandemi Covid-19 untuk menghemat penggunaan istilah yang panjang. Bentuk singkatan memang tidak banyak ditemukan dalam leksikon masa pandemi ini. Apalagi, ketika leksikon itu dikenal masyarakat, kebijakan Gugus Covid-19 malah mengganti bentuk singkatan tersebut (Sagita, 2020). Tulisan ini tidak mempersoalkan masalah penggantian istilah singkatan tersebut dengan istilah yang lain. Yang menjadi sorotan tulisan ini adalah leksikon yang digunakan pada masa pandemi ini yang berkaitan dengan pemanfaatan singkatan sebagai salah cara mudah untuk menyebut sebuah istilah yang panjang. Beberapa singkatan digunakan dalam masa pandemi Covid-19 dapat dilihat dari Tabel 3 berikut.

\begin{tabular}{|c|c|c|c|}
\hline No & Lekem singkatan & Makna & Contoh Kalimat \\
\hline 1 & ODP & Orang dalam pematauan & $\begin{array}{l}\text { ODP merupakan istilah untuk } \\
\text { mengelompokkan individu berdasarkan } \\
\text { beberapa hal seperti gejala demam atau } \\
\text { gangguan pernapasan. }\end{array}$ \\
\hline 2 & PDP & Pasien dalam pengawasan & $\begin{array}{l}\text { PDP adalah singkatan dari pasien dalam } \\
\text { pengawasan. }\end{array}$ \\
\hline 3 & WHO & World health organization & $\begin{array}{l}\text { Di markas WHO di Jenewa, kita akan } \\
\text { disambut oleh warna-warni } 194 \text { bendera } \\
\text { anggota organisasi ini. }\end{array}$ \\
\hline 4 & OTG & Orang tanpa gejala & $\begin{array}{l}\text { OTG adalah singkatan dari orang tanpa } \\
\text { gejala. }\end{array}$ \\
\hline 5 & PSBB & $\begin{array}{l}\text { Pembatasan Sosial Berskala } \\
\text { Besar/karantina kesehatan di } \\
\text { Indonesia }\end{array}$ & $\begin{array}{l}\text { Istilah PSBB sepertinya juga sudah mulai } \\
\text { familiar di telinga masyarakat Tanah Air. }\end{array}$ \\
\hline 6 & PJJ & Pembelajaran jarak jauh & $\begin{array}{l}\text { Pada pembelajaran jarak jauh (PJJ) peserta } \\
\text { didik berbeda tempat dengan pengajar dan } \\
\text { belajar dapat dilakukan di mana pun dan } \\
\text { kapan pun. }\end{array}$ \\
\hline
\end{tabular}

\section{Tabel 3 Leksem Singkatan}

(Sumber: Pasys, 2020)

Singkatan yang digunakan dalam masa pandemi Covid-19 berjumlah enam buah, yaitu ODP (orang dalam pemantauan), PDP (pasien dalam pengawasan), WHO (Worl health organization), OTG (orang tanpa gejala), PSBB (pembatasan sosial berskala besar), dan PJJ (pembelajaran jarak jauh. Singkatan tersebut masih mengikuti 
anjuran tidak lebih dari empat huruf, tidak menimbulkan makna yang berkonotasi negatif, dan pelafalannya mudah disebutkan. Pemerintah Republik Indonesia tidak menggunakan istilah lockdown atau karantina wilayah, tetapi menggunakan istilah pembatasan sosial berskala besar (PSBB) untuk daerah-daerah yang memang berada di zona merah. PSBB adalah singkatan yang popular untuk kota-kota besar di Indonesia yang menerapkannya. Kota-kota besar yang menerapkan PSBB adalah DKI Jakarta, Bandung, Semarang, Surabaya untuk meminimalkan penyebaran Covid-19. Singkatan lain juga memiliki kepopuleran, seperti PJJ. PJJ bukan singkatan yang langsung berhubungan dengan Covid-19, melainkan singkatan yang disebabkan ekses dari Covid19 untuk menunda belajar secara tatap muka. Hasilnya singkatan PJJ juga sangat seksi di masa pademi ini. Meskipun kalangan akademisi telah mengenalnya pembelajaran jarak jauh (PJJ) ketika dibukanya Universitas Terbuka (UT), masa pandemi Covid-19 menjadikan PJJ lebih dikenal luas di seluruh lapisan masyarakat.

\section{SIMPULAN}

Berdasarkan permasalahan dalam tulisan ini dapat ditegaskan bahwa leksikon masa Sar-Cov sampai dengan masa pandemi Covid-19 produksinya tidak berimbang. Artinya, leksikon masa SAR-Cov memang tidak menimbulkan lahirnya leksikon baru karena penyakit itu tidak berkembang di Indonesia begitu juga pada masa MERS-Cov. Masyarakat Indonesia yang akan berpergian ke luar negeri dianjurkan untuk mematuhi protokol kesehatan supaya tidak tertular SAR-Cov dan MERS-Cov pada masanya. Namun, masa pandemi Covid-19 tidak hanya menyerang negara luar, tetapi juga menyerang Indonesia dan berkembang dengan pesat orang yang terpapar Covid-19. Kondisi ini menghasilkan leksikon masa pandemi Covid-19 yang bervariasi dari leksem primer (LP), leksem sekunder (LS), dan singkatan. Leksem primer yang sangat terkenal masa pandemi ini adalah pandemi, masker. Leksem sekunder yang sangat popular masa pandemi Covid-19 adalah Covid-19 karantina wilayah, tes rapid, dan tes swab, kenormalan baru (new normal), zona merah, PSBB. Leksikon-leksikon tersebut menjadi penananda utama bahwa masa pandemi menghasilkan banyak leksikon dalam memperkaya bahasa Indonesia. Di samping itu, leksikon tersebut menjadi ciri utama atau penanda utama suatu peristiwa sejarah, yaitu sejarah Covid-19 di Indonesia khususnya dan di dunia umumnya.

\section{UCAPAN TERIMA KASIH}

Penulis ucapkan terima kasih kepada teman-teman Balai Bahasa Provinsi Jawa Barat yang telah membantu dengan buku-buku referensi untuk menyelesaikan artikel ini.

\section{DAFTAR PUSTAKA}

Akbari, S. (2020). Pesan Berbahasa Banjar dan Pandemi Covid-19. Semarang.

Budi, N. (2020). Istilah-Istilah yang Berkaitan dengan COVID-19. Retrieved from https://www.liputan6.com/bola/read/4214575/saat-pandemi-corona-covid-19-27- 
istilah-populer-yang-harus-dimengerti-dari-novel-sampai-viral-load.

J. Lyons. (1968). Intorductions to Theorical Linuistics. Cambridge: Cambridge University Press.

Kridalaksana, H. (1993). Kamus Linguistik (Edisi Keti). Jakarta: Gramedia Pustaka.

Kridalaksana, H. (2009a). Pembentukan Kata dalam Bahasa Indonesia. Jakarta: Gramedia Pustaka Utama.

Kridalaksana, H. (2009b). Pembentukan Kata dalam Bahasa Indonesia (Cetakan Ke). Jakarta: Gramedia Pustaka Utama.

Kridalaksana, H. (2009c). Pembentukan Kata dalam Bahasa Indonesia. Jakarta: Gramedia Pustaka Utama.

Kumar, Dharmahendra, Rishabha Malviya, and P. K. S. (2020). Corona Virus: A

Review of COVID-19. Eurasian Journal of Medicine and Oncology, 2/4, 8--25.

Mahsun, M. S. (2014). Metode Penelitian Bahasa: Tahapan Strategi Metode dan Tekniknya. Jakarta: Raja Grafindo Persada.

Nasional, D. P. (2008). Kamus Besar Bahasa Indoesia Edisi IV. Jakarta: Gramedia Pustaka Utama.

Nugraha, A. S. (2020). Kearifan Lokal dalam Menghadapi Covid-19 Sebuah Kajian Literatur, 10/1, 745--753. Retrieved from homepage: http://ejournal.upi.edu/index.php/sosietas

Pasys, R. (2020). Apa Itu Zona Hijau, Zona Merah hingga Zona Hitam Terkait Virus

Corona. Retrieved from https://kids.grid.id/read/472179856/apa-itu-zona-hijauzona-merah-hingga-zona-hitam-terkait-virus-corona?page=all

Ristyawati, A. (2020). Efektifitas Kebijakan Pembatasan Sosial Berskala Besar Dalam Masa Pandemi Corona Virus 2019 oleh Pemerintah Sesuai Amanat UUD NRI Tahun 1945, 3(2), 240-249.

Sagita, S. N. (2020). Kemenkes Hapus Istilah ODP-PDP-OTG Corona, Akan Seperti Apa Dampaknya. Retrieved from https://health.detik.com/berita-detikhealth/d5092488/kemenkes-hapus-istilah-odp-pdp-otg-corona-akan-seperti-apadampaknya

Sampurno, Muchammad Bayu Tejo, Tri Cahyo Kusumandyoko, M. A. I. (n.d.). Budaya Media Sosial , Edukasi Masyarakat dan Pandemi, (Covid 19). https://doi.org/10.15408/sjsbs.v7i5.15210

Verhaar, J. W. M. (2001). Asas-Asas Linguistik Umum. Yogyakarta: Gadjah Mada University Press.

Wulandari, Ari, Marsono, dan S. (2018). Pandangan Penutur Bahasa Jawa terhadap Cacar: Kajian Etnolinguistik. Mozaik Humaniora, 18/1, 15--23.

\section{HASIL DISKUSI \\ Tidak ada pertanyaan}

